\title{
Defoliation tolerance and ammonium uptake rate in perenni- al tussock grasses
}

\author{
CAROLINA SAINT PIERRE, CARLOS ALBERTO BUSSO, OSCAR MONTENEGRO, GUSTAVO D. RODRIGUEZ, \\ HUGO D. GIORGETTI, TOMAS MONTANI, AND OSCAR A. BRAVO
}

At the time of this research, Saint Pierre was Fellow of the Consejo Nacional de Investigaciones Cientificas y Técnicas de la República Argentina (CONICET), Altos del Palihue, Bahia Blanca (8000), Argentina; Busso is full Professor, Departamento de Agronomía, Universidad Nacional del Sur (UNS) and research scientist of CONICET, Altos del Palihue, Bahía Blanca (8000), Argentina; Montenegro, Rodriguez and Giorgetti are research scientists, Chacra Experimental de Patagones, Ministerio de Agricultura, Ganaderia y Pesca, cc 118, Carmen de Patagones (8504), Argentina; and Montani and Bravo are assistant Professor and Teaching Assistant, respectively, Departamento de Agronomia UNS, Altos del Palihue, Bahía Blanca (8000), Argentina.

\section{Abstract}

Stipa clarazii, Ball. has been shown to be more tolerant to defoliation and a superior competitor to $S$. tenuis Philo and $S$. ambigua Speg. 3 perennial grasses native to semiarid rangelands in central Argentina. Mechanisms contributing to its great defoliation tolerance and competitive ability, however, are largely unexplored. We examined tolerance to defoliation and ammonium uptake rates on defoliated and undefoliated plants of those species at 10, 25, and 50 ppm $\mathrm{NH}_{4}^{+}$using $\left(\mathrm{NH}_{4}\right)_{2} \mathrm{SO}_{4}$ solutions containing 60 atom $\%{ }^{5} \mathrm{~N}$ excess. By mid-spring, greater regrowth following defoliation in $S$. clarazii than in $S$. tenuis or $S$. ambigua indicated greater defoliation tolerance in the first than in the other 2 species. Stipa clarazii had similar of higher ammonium uptake rates than $S$. tenuis and $S$. ambigua. Higher ammonium uptake rates in $S$. clarazii thus appear to be one of the mechanisms most likely contributing to its greater competitive ability and defoliation tolerance when compared to the other 2 species. Defoliated plants of all 3 species had similar or greater ammonium uptake rates than undefoliated plants. These results suggest that photosynthetic canopy reestablishment may be achieved without sacrificing root function in these perennial grasses, at least as long as carbon reserves do not become a limiting factor. Ammonium uptake rates increased when $\mathrm{NH}_{4}{ }^{+}$concentrations increased in the labeled solutions in $S$. clarazii, $S$. tenuis and $S$. ambigua. This result demonstrates the capacity of the root system for increasing nutrient acquisition during periods of high resource availability.

Key Words: competitive ability, defoliation, ${ }^{15} \mathrm{~N}$, perennial grasses, uptake rate

Differences in resource acquisition and competitive ability among species within the same plant community have been linked to a variety of plant traits and mechanisms (Nye and Tinker 1977, Caldwell 1994). Ammonium uptake rate and competitive ability are positively related (Jackson and Caldwell 1989, Caldwell 1994) mainly in low-productivity environments where belowground resource competition is intense (Casper and Jackson 1997). In addition, greater competitive ability has been reported

Corresponding author: Departamento de Agronomia UNSur, Altos del Palihue, 8000-Bahia Blanca, Argentina; email: cebusso@criba.edu.ar; fax: 54-2914595127; Phone: 54-0291-4595126/4595102.

Manuscript accpeted 11 May 03.

\section{Resumen}

Se ha demostrado que Stipa clarazii tiene una mayor tolerancia a la defoliación y capacidad competitiva que $S$. tenuis y $S$. ambigua, 3 especies de gramíneas perennes nativas en los pastizales naturales semiáridos del centro de Argentina. Los mecanismos que contribuyen a determinar su mayor tolerancia a la defoliación y capacidad competitiva, sin embargo, todavia no se han investigado. Se examinaron la tolerancia a la defoliación y las tasas de absorción de amonio en plantas defoliadas y no defoliadas de estas especies a 10, 25, y 50 ppm $\mathrm{NH}_{4}{ }^{+}$usando soluciones de $\left(\mathrm{NH}_{4}\right)_{2} \mathrm{SO}_{4}$ que contenian un enriquecimiento de ${ }^{15} \mathrm{~N}$ del $60 \%$. A mediados de primavera, una mayor producción de rebrote luego de la defoliación en S. clarazii que en S. tenuis y S. ambigua indicó una mayor tolerancia a la defoliación en la primera que en las otras dos especies. Stipa clarazii tuvo tasas de absorción de amonio similares o superiores, pero no menores, que $S$. tenuis y $S$. ambigua. Mayores tasas de absorción de amonio parecen ser uno de los mecanismos que contribuyen a determinar la mayor capacidad competitiva y tolerancia a la defoliación en Stipa clarazii que en las otras dos especies. Las plantas defoliadas de las tres especies tuvieron tasas de absorción de amonio similares o mayores que las plantas no defoliadas. Estos resultados sugieren que la restitución de la superficie fotosintetica se puede obtener sin sacrificar la función radical en estas especies, siempre y cuando las reservas de carbon no sean un factor limitante. Las tasas de absorcion de amonio fueron mayores cuando se incremento la concentración de $\mathrm{NH}_{4}{ }^{+}$en las soluciones marcadas en Stipa clarazii, S. tenuis y S. ambigua. Este resultado demuestra la capacidad. del sistema radical para incrementar la adquisición de nutrientesdurante periodos de alta disponibilidad de recursos.

as one of the major mechanisms contributing to greater defoliation tolerance in perennial grasses (Briske and Richards 1995). Physiological plasticity of the root system in its nutrient uptake capacity is also important in nutrient-poor environments (Larigauderie and Richards 1994). This physiological root plasticity allows for a disproportionate increase in ammonium uptake rate (i.e., uptake kinetics) per unit root mass or length whenever an N-rich patch is found (Caldwell 1994, Jackson et al. 1999). This mechanism can be particularly important when soil resource availability is temporally or spatially unpredictable, and when 


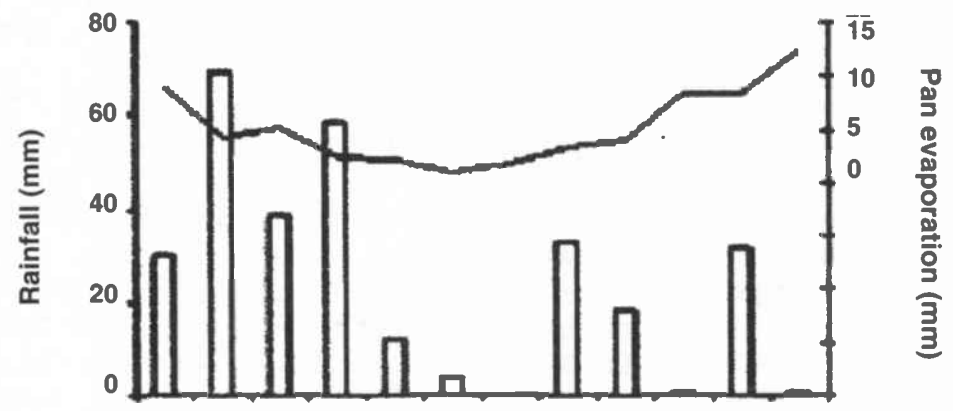

B
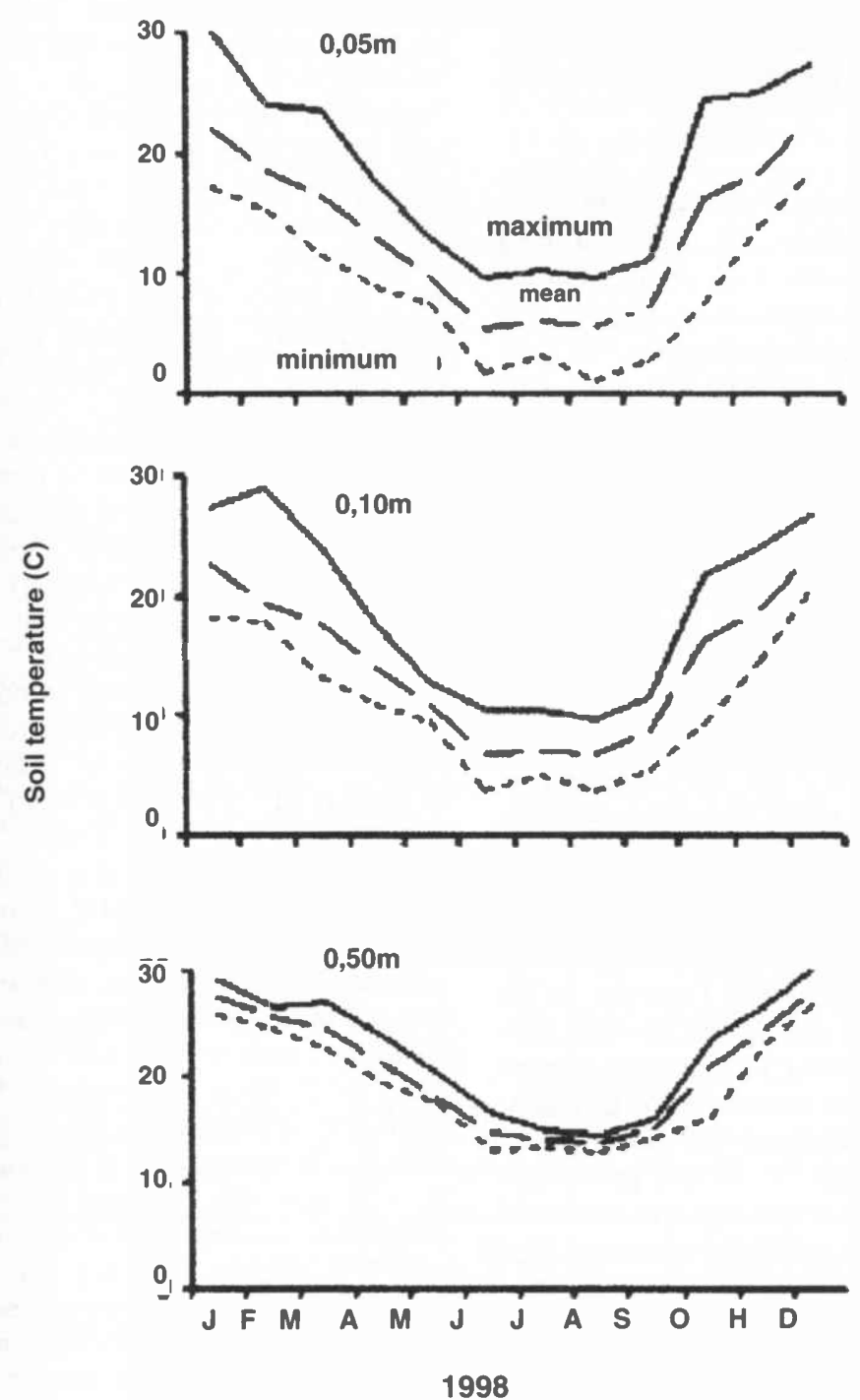

Fig. 1. A) Daily rainfall (mm; vertical bars) and PAN evaporation ( $\mathrm{mm}$; solid line), and B) Absolute maximum and minimum, and mean monthly soil temperatures measured at 0900 hours at $0.05,0.10$, and $0.50 \mathrm{~m}$ soil depth during 1998 at a meteorological station located at the study site. duration and magnitude of nutrient pulses are insufficient to compensate for costs associated with root morphological plasticity (Grime 1994).

Carbohydrate flow from shoots to roots has a direct role in regulating plant nitrogen uptake (Rideout and Raper 1994). Mechanisms of soil resource acquisition can then be directly or indirectly affected after defoliation by either reducing plant photosynthetic capacity or preferentially allocating carbon to shoot regrowth (Briske and Richards 1995). In this manner, herbivory may modify competitive interactions among plant species in grazed communities (Briske 1991). Defoliation can reduce (Sanderson et al. 1997), have no effect or even increase (Wallace 1981, Polley and Detling 1989) N uptake rates. An understanding of the ways plants respond to defoliation is useful in predicting competitive outcomes after grazing in natural systems (Wallace and Macko 1993).

Stipa clarazii Ball (big needlegrass), $S$. lenuis Phil. (thin needlegrass) and $S$. ambigua Speg. (viscacha hole straw), all perennial grass species, have shown different responses to continuous, long-term grazing in rangelands of the south of the Phytogeographical Provinces of the Monte and Espinal (Busso 1997). Stipa clarazii is an example of a palatable (Cano 1988), dominant, highly competitive grass species in exclosures or lightly grazed areas (Busso 1997, Giorgetti et al. 1997, Saint Pierre et al. 2002). Mean values for neutral detergent fiber and crude protein in this species are 69.7 and $13.7 \%$, respectively at the vegetative developmental stage (Moretto and Distel, 1997). Under moderate continuous grazing, $S$. clarazii is replaced by other comparatively less palatable, perennial grasses like $S$. tenuis (Busso 1997). This species has mean values of $71.9 \%$ for neutral detergent fiber and $12.9 \%$ for crude protein at the vegetative stage of development (Torrea et al. 2000). Selective heavy grazing of these palatable perennial grasses, however, will eventually lead to their replacement by other unpalatable, early-successional, less competitive species (Briske 1991, Anderson and Briske 1995). Thus, $S$. clarazii and $S$. tenuis have been replaced by the unpalatable $S$. ambigua under continuous, severe grazing conditions in semiarid rangelands of central Argentina (Giorgetti et al. 1997). Mean values in $S$. ambigua are $9.4 \%$ for lignin and $8.9 \%$ for crude protein early in the growing season (Giorgetti, Montenegro and Rodriguez, Chacra Experimental de Patagones, unpublished data). 
Parallel studies conducted at our study site have shown a greater competitive ability and tolerance of defoliation in $S$. clarazii than in S. tenuis and S. ambigua (Saint Pierre 2002). For example, regrowth has been greater in $S$. clarazii than in the other 2 species after 2 successive defoliations (Saint Pierre et al. 2000a, 2000b). This has been associated with greater relative growth rates for green tiller length and height, and greater tiller production in S. clarazii than in S. tenuis and $S$. ambigua (Saint Pierre et al. 2000a). Root proliferation towards root-free disturbed soil has also been greater on defoliated and undefoliated plants of $S$. clarazii than on those of $S$. tenuis and $S$. ambigua (Saint Pierre et al. 2002). However, studies have not been conducted to determine if ammonium uptake rates could be another mechanism contributing to the greater defoliation tolerance and competitive ability in $S$. clarazii than in the other 2 species.

We evaluated defoliation tolerance and competitive ability in defoliated and undefoliated plants of S. clarazii, S. tenuis and $S$. ambigua. Competitive ability was determined by measuring ammonium uptake rates at different $\mathrm{NH}_{4}{ }^{+}$concentrations using $\left(\mathrm{NH}_{4}\right)_{2} \mathrm{SO}_{4}$ solutions containing 60 atom $\%{ }^{15} \mathrm{~N}$ excess. We predicted that: (1) defoliation tolerance and ammonium uptake rates are greater in $S$. clarazii than in S. tenuis and S. ambigua, and (2) ammonium uptake rate is reduced by defoliation in all 3 species.

\section{Materials and Methods}

\section{Study area}

Research was done from May to December 1998 at the field site of the Experimental Farm of Patagones ( $40^{\circ} 39^{\prime} \mathrm{S}$, $62^{\circ} 54^{\prime} \mathrm{W} ; 40 \mathrm{~m}$ elevation), $22 \mathrm{~km}$ north of Carmen de Patagones. It was conducted in a community that had been protected from domestic herbivores since 1996, because it contained abundant populations of lateand earlier-seral perennial grasses. The study site is within the Phytogeographical Province of the "Monte" (Cabrera 1976). The community is characterized as an open shrubby habitat with mostly perennial grasses (Giorgetti et al. 1997). The soil was classified as a Typic haplocalcid with a $20 \mathrm{~cm}$ thick A horizon with a loamyclay-sandy texture; $16.9 \mathrm{~g} \mathrm{~kg}^{-1}$ organic carbon; $28.7 \mathrm{ppm}$ available phosphorus and $1.23 \mathrm{~g} \mathrm{~kg}^{-1}$ total nitrogen. $\mathrm{A} \mathrm{B}_{\mathrm{w}}$ horizon was found below $0.20 \mathrm{~m}$ soil depth followed by a $\mathrm{BC}_{\mathrm{k}}$ horizon between 0.28 and $0.43 \mathrm{~m}$ depth. $\mathrm{A}_{\mathrm{k}}$ horizon was below $0.43 \mathrm{~m}$ depth with very few roots. Long term (1901-1950) average annual climate values are: $331 \mathrm{~mm}$ precipitation, $14.6^{\circ} \mathrm{C}$ temperature, $60 \%$ relative humidity and $13 \mathrm{~km} /$ hour wind speed. More recent records for precipitation (1981-2000), however, raise the previous average annual value to $442.9 \mathrm{~mm}$. Average minimum (August) and maximum (January) temperatures are -7.6 and $43 \mathrm{C}$, respectively. Monthly precipitation and pan evaporation during the research period were registered by a meteorological station at the study site. Thermal records are also provided for soil temperature since it has big effects on root respiration, and respiration affects ammonium uptake (Fig 1)

\section{Treatments and measurements}

Seventy two plants, 24 of each of the 3 species ( $S$. clarazii, $S$. tenuis and $S$. ambigua), were marked on 22 May. On each plant, shoot circumference was measured at the soil surface. The study area within the 2 year-exclosure had a good plant cover partly because it had been grazed appropriately in previous years. Most plants were close to one another in that community. However, and similarly to that reported by Busso et al. (2001), we selected those without nearby neighbors within a radius of at least $0.30 \mathrm{~m}$ to decrease the probability of including roots from adjacent species. Half of the plants was defoliated to $5 \mathrm{~cm}$ stubble height on 17 September (apical meristems were not removed from the plants) and 12 October (apical meristems at the reproductive stage of development were removed), while the other half remained undefoliated (controls). No clipping was imposed on all studied tussocks during the previous dormant, warm season so that only current year aboveground growth could be evaluated in both defoliated and undefoliated plants. Thus, only dry weight production after defoliation (regrowth) was measured in this study on defoliated plants of all 3 species. Comparison of dry weight production on a per plant basis was prevented because of inherent plant basal area variation among species (mean values \pm 1 standard error $\left(\mathrm{cm}^{2}\right)$ were $53.9 \pm 5.7$ in $S$. clarazii, $72.5 \pm 6.3$ in $S$. tenuis and 111.2 \pm 15.2 in S. ambigua). Therefore, dry weight production data will be reported on a per basal area basis. All plant tissues obtained above clipping height were ovendried at $60^{\circ} \mathrm{C}$ and then weighed.

Three destructive harvests were conducted during spring on the following dates: 6-10 days after the first defoliation (26 September), 6-10 days after the second defoliation (22 October), and at the end of the growing season (4 December). Entire plants including a block of soil approximately 25 (length) x 25 (wide) $x$ 30 (depth) $\mathrm{cm}$ were excavated. Although these soil samples did not capture the entire root system, they did contain many fine lateral roots. Also, Becker et al. (1997) found that root weight density of field-grown S. tenuis and Piptochaetium napostaense (Speg.) Hack., another native perennial grass in central Argentina, was more than 2 times higher at $0-0.25 \mathrm{~m}$ than at $0.25-0.50 \mathrm{~m}$ soil depth. Four plants were harvested per species and defoliation treatment on each sampling date.

Roots for the $\mathrm{N}$ absorption experiment were manually washed from the soil, floated in water and retained if they were $\leq 1$ $\mathrm{mm}$ in diameter and had a light color characteristic of young roots. By using excised roots, we removed them from their 'ecological reality'. The excised root assay was designed to provide relative comparisons of ammonium uptake, and there is evidence that the rate of uptake of ammonium in excised grass roots is representative of intact-root uptake if measurements are completed within the first 2 hours after excision (Bloom and Caldwell 1988). Then, we took precautions to complete the ${ }^{15} \mathrm{~N}$ uptake experiments within $2-2.5$ hours after soil sample collection in the field, precautions which have been followed extensively in this type of study (i.e., Jackson et al. 1990, Derner and Briske 1999, Busso et al. 2001). During separation, roots were maintained in aerated, 0.5 $\mathrm{mM} \mathrm{CaCl} 2$ solutions at $20 \mathrm{C}$. Roots from individual plants were separated into 3 subsamples of $0.5-1 \mathrm{~g}$ dry weight, wrapped in cheese cloth bags, and equilibrated for 1 hour in a $0.5 \mathrm{mM} \mathrm{CaCl}_{2}$ solution at $20 \mathrm{C}$. Roots were immersed for 10 minutes in solutions of $\left(\mathrm{NH}_{4}\right)_{2} \mathrm{SO}_{4}(60$ atom $\%{ }^{15} \mathrm{~N}$ excess) which contained 10 , 25 or $50 \mathrm{ppm} \mathrm{NH}_{4}{ }^{+}$. Typical soil solution ammonium concentrations at the site were $6.58: \pm 0.37 \mathrm{ppm}$ (mean: \pm S.E., $n=9$; range $=5.18-8.40 \mathrm{ppm})$ on soil samples taken up to $30 \mathrm{~cm}$ depth in midwinter (16 July 1998). This value is similar to that reported by Sanchez and Lazzari (1999) in another rangeland in central, semiarid Argentina. The highest concentration was selected to represent enriched soil patches where solution concentrations were approximately 2 times higher than typically found in native soils. Differences in the spatial and temporal distribution of nutrient transformation and consumption 
processes result in soil patches of differing concentrations, and the resistance to diffusion and mass flow between regions of high and low concentration contributes to maintenance of patches (Stark 1994). Fertilizer use efficiency (plant $\mathrm{N}$ absorption/total $N$ applied $x 100$ ) is at the most $30 \%$ in this semiarid region (Lazzari et al. 1991).

All solutions were mixed well and aerat-

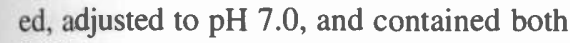
$0.01 \mathrm{M}$ sucrose as an energy source and $0.5 \mathrm{mM} \mathrm{CaCl}_{2}$ to maintain membrane integrity (Jackson et al. 1991, Vucinic and Vuletic 1995). Soil samples obtained at the study site on $16 \mathrm{July} \mathrm{had} \mathrm{a} \mathrm{pH}$ of $7.0 \pm$ $0.1(n=4$; range $=6.9-7.1)$. Giorgetti et al. (1997) reported a similar value at the same study site. Root subsamples were then rinsed 3 times for a minimum of 2 minutes in unlabeled $50 \mathrm{mM}\left(\mathrm{NH}_{4}\right)_{2} \mathrm{SO}_{4}$ solutions at $5 \mathrm{C}$. The rinse solutions were designed to replace any ${ }^{15} \mathrm{~N}$ adsorbed on the roof surfaces. Roots were blotted dry, oven-dried at $60^{\circ} \mathrm{C}$, weighed and ground through a 40-mesh screen. Approximately $100 \mathrm{mg}$ of biomass were used for analyzing $\mathrm{N}$ and ${ }^{15} \mathrm{~N}$ content. Total $\mathrm{N}$ content in plant material was determined following a Kjeldahl modified procedure (Fiedler and Proksch 1975). The ${ }^{14} \mathrm{~N}^{15} \mathrm{~N}$ ratio was measured after a Rittemberg oxidation (Rittemberg 1948) on a NO16 PC emission spectrometer (Comisi6n Nacional de Energia At6mica, Ezeiza, Bs.As.). Mean ( \pm 1 standard error, $\mathrm{n}=11$ ) background ${ }^{15} \mathrm{~N}$ atom $\%$ values $(0.38082 \% \pm 0.00406)$ were subtracted from labeled samples to determine ${ }^{15} \mathrm{~N}$ atom \% excess values.

\section{Statistical analysis}

Dry weight (regrowth) data were analyzed using one-way ANOVA and a com-

Table 1. Dry weight production (regrowth) per basal area basis on defoliated plants of $S$. clarazii, $S$. tenuis and S. ambigua on early (26 September) and mid-spring (22 October) and at the end of the growing season (4 December). Each value is the mean \pm 1 s.e.m. of $n=4$. Means within rows followed by a different letter are statistically different $(\mathrm{P}<0.05)$.

\begin{tabular}{lccc}
\hline \hline $\begin{array}{l}\text { Sampling } \\
\text { Date }\end{array}$ & $\begin{array}{c}\text { Regrowth production } \\
\text { S. clarazii }\end{array}$ & S. tenuis & S. ambigua \\
\hline & & & \\
& & & \\
26 September & $0.001 \pm 0.0004 \mathrm{a}$ & $0.003 \pm 0.0011 \mathrm{a}$ & $0.003 \pm 0.0010 \mathrm{a}$ \\
22 October & $0.009 \pm 0.0036 \mathrm{a}$ & $0.002 \pm 0.0007 \mathrm{~b}$ & $0.001 \pm 0.0003 \mathrm{~b}$ \\
2 December & $0.042 \pm 0.0159 \mathrm{a}$ & $0.019 \pm 0.0085 \mathrm{a}$ & $0.010 \pm 0.0051 \mathrm{a}$ \\
\hline
\end{tabular}

pletely randomized experimental design. For the ammonium uptake rate data, an experimental design analogous to a splitplot design was used in this study. Response variables were date, species, defoliation treatment and ammonium concentration. For each plant, roots $\leq 1 \mathrm{~mm}$ in diameter were randomly selected from the total root pool using 4 replicates (plants) per treatment on each of 3 harvesting dates. Square-root transformed data were used for analysis to homogenize variances. A four-way ANOVA was initially performed. Interactions were decomposed to evaluate $\mathrm{NH}_{4}{ }^{+}$concentration and species effects. LSD was utilized for mean separation when $\mathrm{F}$ tests were significant $(\mathrm{P}=$ 0.05) (Steel and Torrie 1981).

\section{Results}

Dry weight production after defoliation (regrowth) was similar or greater $(\mathrm{P}<$ 0.05 ) in $S$. clarazii than in $S$. tenuis and $\mathrm{S}$. ambigua (Table 1). In all 3 sampling dates, ammonium uptake rates were similar or greater $(p<0.05)$ at higher than lower $\mathrm{NH}_{4}{ }^{+}$concentrations on defoliated and undefoliated plants of $S$. clarazii, $S$. tenuis and $S$. ambigua (Table 2). At the first sampling date, ammonium uptake rates were similar $(\mathrm{P}>0.05)$ among species and defoliation treatments for 10 and $25 \mathrm{ppm} \mathrm{NH}_{4}{ }^{+}$concentrations (Table 2). However, undefoliated plants of $S$. clarazii showed higher $(\mathrm{P}<0.05)$ ammonium uptake rates than defoliated and undefoliated plants of $S$. tenuis and $S$. ambigua at $50 \mathrm{ppm} \mathrm{NH}_{4}{ }^{+}$concentration. On 22 October, rates of ammonium uptake were similar $(\mathrm{P}>0.05)$ among species and defoliation treatments at 10 and $50 \mathrm{ppm}$ $\mathrm{NH}_{4}{ }^{+}$concentrations (Table 2). At $25 \mathrm{ppm}$ $\mathrm{NH}_{4}{ }^{+}$in the labeled solution, however, $\mathrm{f}$ defoliated plants of $S$. clarazii had greater $(P>0.05)$ ammonium uptake rates than defoliated plants of $S$. tenuis or undefoliated plants of S. ambigua (Table 2). Rates of ammonium uptake were greater $(\mathrm{P}>0.05)$ on defoliated than on undefoliated plants in S. ambigua.

Undefoliated plants of $S$. clarazii showed greater $(P>0.05)$ ammonium uptake rates than defoliated plants of $S$. tenuis at the lowest $\mathrm{NH}_{4}{ }^{+}$concentration by the end of the growing season (Table 2). At this time, ammonium uptake rates were similar among species or defoliation treatments at $25 \mathrm{ppm} \mathrm{NH}_{4}{ }^{+}$. At $50 \mathrm{ppm}$

Table 2. Ammonium uptake rates ( $\mu \mathrm{g} \mathbf{N}$ g root dry weight ${ }^{-1}$ hour $^{-1} ; \mathrm{n}=4$ ) for undefoliated and defoliated plants of $S$. clarazii, $S$. tenuis and $S$. ambigua in a semiarid rangeland in central Argentina. Roots were subsampled and immersed in solutions of $\left(\mathrm{NH}_{4}\right)_{2} \mathrm{SO}_{4}\left(60\right.$ atom \% ${ }^{15} \mathrm{~N}$ excess) which contained 10, 25, or $50 \mathrm{ppm} \mathrm{NH}_{4}{ }^{+}$on early (26 September) and mid-spring (22 October), and at the end of the growing season (4 December).

\begin{tabular}{|c|c|c|c|c|c|c|c|c|c|c|}
\hline & & \multicolumn{3}{|c|}{26 Sept. } & \multicolumn{3}{|c|}{22 Oct. } & \multicolumn{3}{|c|}{4 Dec. } \\
\hline & & $10 \mathrm{ppm}$ & $25 \mathrm{ppm}$ & $50 \mathrm{ppm}$ & $10 \mathrm{ppm}$ & $25 \mathrm{ppm}$ & $50 \mathrm{ppm}$ & $10 \mathrm{ppm}$ & $25 \mathrm{ppm}$ & $50 \mathrm{ppm}$ \\
\hline & Undefoliated & $57.8 \mathrm{a}^{*}, \mathrm{a}^{* *}$ & $89.8 \mathrm{a}, \mathrm{ab}$ & $194.4 \mathrm{a}, \mathrm{b}$ & $46.7 \mathrm{a}, \mathrm{a}$ & $63.1 \mathrm{abc}, \mathrm{a}$ & $100.9 \mathrm{a}, \mathrm{b}$ & $62.7 \mathrm{a}, \mathrm{a}$ & $63.3 \mathrm{a}, \mathrm{a}$ & $73.4 \mathrm{a}, \mathrm{a}$ \\
\hline \multicolumn{11}{|l|}{ S. clarazii } \\
\hline & Defoliated & $57.3 \mathrm{a}, \mathrm{a}$ & $75.5 \mathrm{a}, \mathrm{a}$ & $131.9 \mathrm{ab}, \mathrm{b}$ & $50.7 \mathrm{a}, \mathrm{a}$ & $94.7 \mathrm{a}, \mathrm{a}$ & 84.9 a, a & $37.6 \mathrm{ab}, \mathrm{a}$ & $54.7 \mathrm{a}, \mathrm{b}$ & $77.8 \mathrm{a}, \mathrm{c}$ \\
\hline & Undefoliated & $57.7 \mathrm{a}, \mathrm{a}$ & $82.1 \mathrm{a}, \mathrm{a}$ & $97.1 \mathrm{~b}, \mathrm{a}$ & $46.8 \mathrm{a}, \mathrm{a}$ & $67.0 a b c, a b$ & $88.3 \mathrm{a}, \mathrm{b}$ & $36.4 \mathrm{ab}, \mathrm{a}$ & 49.9 a, a & $39.2 \mathrm{~b}$, a \\
\hline \multicolumn{11}{|l|}{ S. tenuis } \\
\hline & Defoliated & $50.1 \mathrm{a}, \mathrm{a}$ & $85.8 \mathrm{a}, \mathrm{b}$ & $81.0 \mathrm{~b}, \mathrm{~b}$ & $54.3 \mathrm{a}, \mathrm{a}$ & $48.6 \mathrm{bc}, \mathrm{a}$ & $87.5 \mathrm{a}, \mathrm{b}$ & $33.5 \mathrm{~b}, \mathrm{a}$ & $64.9 \mathrm{a}, \mathrm{ab}$ & $80.8 \mathrm{a}, \mathrm{b}$ \\
\hline & Undefoliated & $44.2 \mathrm{a}, \mathrm{a}$ & 90.9 a, b & $94.9 \mathrm{~b}, \mathrm{~b}$ & $53.1 \mathrm{a}, \mathrm{a}$ & $39.7 \mathrm{c}, \mathrm{a}$ & 74.5. a, b & $41.3 \mathrm{ab}, \mathrm{a}$ & $60.1 \mathrm{a}, \mathrm{a}$ & $54.0 \mathrm{~b}, \mathrm{a}$ \\
\hline \multicolumn{11}{|l|}{ S. ambigua } \\
\hline & Defoliated & $78.1 \mathrm{a}, \mathrm{a}$ & $100.9 \mathrm{a}, \mathrm{a}$ & $104.8 \mathrm{~b}, \mathrm{a}$ & $39.1 \mathrm{a}, \mathrm{a}$ & $72.4 \mathrm{ab}, \mathrm{b}$ & $93.5 \mathrm{a}, \mathrm{b}$ & $53.3 \mathrm{ab}, \mathrm{a}$ & $43.3 \mathrm{a}, \mathrm{a}$ & $87.9 \mathrm{a}, \mathrm{b}$ \\
\hline
\end{tabular}

*Within columns, different letters to the left of the comma indicate significant differences $(\mathrm{P}<0.05)$ within each concentration and sampling date.

**Within rows, different letters to the right of the comma indicate significant differences $(\mathrm{P}<0.05)$ within each species, defoliation treatment and sampling date. 
labelled $\mathrm{NH}_{4}^{+}$however, undefoliated and defoliated plants of $S$. clarazii showed greater $(\mathrm{P}<0.05)$ ammonium uptake rates than undefoliated plants of $S$. tenuis and $S$. ambigua (Table 2). Also, ammonium uptake rates were greater $(P<0.05)$ on defoliated than on undefoliated plants in $S$. tenuis and $S$. ambigua.

\section{Discussion}

By mid-spring, Stipa clarazii showed greater regrowth following defoliation than $S$. tenuis and S. ambigua. This result indicates greater defoliation tolerance in $S$. clarazii than in S. tenuis and S. ambigua. A rapid photosynthetic surface area reestablishment is characteristic of perennial grasses tolerant to defoliation (Caldwell et al. 1981, Briske and Richards 1995, Briske and Hendrickson 1998). In addition, greater growth of any given species may have implications in the capacity for soil resource acquisition. For example, when 2 perennial grass species (Schizachyrium scoparium and Paspalum plicatulum) grew near each other, the species with greater growth was potentially released from nutrient limitation as a result of lower growth in the other species Under these conditions, $S$. scoparium took advantage of unused resources by $P$. plicatulum which indicated a significant competitive intensity (Van Auken and Bush 1997).

Proportional increases in the magnitude of ammonium uptake rate over a relatively wide range of increasing $\mathrm{NH}_{4}{ }^{+}$solution concentrations indicate that an efficient uptake kinetics is an important component for ammonium acquisition in S. clarazii, $S$. tenuis and $S$. ambigua. A similar conclusion was reached by Derner and Briske (1999) on several $C_{3}$ and $C_{4}$ perennial grass species. Increases in nutrient uptake as a result of higher soil resource availability in low-nutrient adapted plants would demonstrate the capacity of the root system in these species to take advantage of greater soil resource levels when they are available (Crick and Grime 1987). Since presence of nearby plants can substantially modify ammonium uptake rate of target individuals (e.g., Wallace and Macko 1993), targets were chosen such that they had no neighbors within a radius of at least $0.30 \mathrm{~m}$. Similar distances among plants have been reported in other studies determining ammonium uptake rates in perennial grasses (Jackson and Caldwell 1991, Busso et al. 2001). Rates of ammonium uptake were similar or greater, but not lower, in $S$. clarazii than in $S$. tenuis and S. ambigua at high concentrations. This suggests a greater efficiency for ammonium uptake in $S$. clarazii than in the other 2 species. On average for all sampling times, ammonium concentrations and defoliation treatments, ammonium uptake rates were $>13 \%$ greater in $S$. clarazii $\left(78.7 \mu \mathrm{g} \mathrm{N} \mathrm{g}\right.$ root dry weight ${ }^{-1} \mathrm{~h}^{-1}$ than in $S$. tenuis $(63.9 \mu \mathrm{g} \mathrm{N}$ g root dry weight $^{-1}$ hour $\left.^{-1}\right)$ and S. ambigua $(68.1 \mu \mathrm{g} \mathrm{N}$ $\mathrm{g}$ root dry hour ${ }^{-1}$ ). Even though the number of replicate plants used in our investigation is similar to that used in other studies of ammonium uptake (i.e., Derner and Briske 1999, Busso et al. 2001), it may be that it was not high enough as to detect more significant differences among species. Our results are similar to those reported by Busso et al. (2001), who found that the late-seral Eriochloa sericea (Texas cupgrass) had significantly greater rates of ${ }^{15} \mathrm{~N}$ uptake than the late-seral Bouteloua curtipendula (sideoats grama) in only 3 out of 21 comparisons.

The greater ammonium uptake rate in $S$. clarazii than in the other 2 species, in agreement with the first hypothesis, confirms the positive correlation between competitive ability and ammonium uptake rate which has been reported by several authors (Nye and Tinker 1977, Jackson and Caldwell 1989, Wallace and Macko 1993, Caldwell 1994). However, differences in competitive ability may also be the result of other characteristics of physiological processes and carbon allocation patterns within any species (Di Tommaso and Aarssen 1991). For example, a greater root proliferation capacity in S. clarazii than in $S$. tenuis and $S$. ambigua also appears to be important in determining its greater competitive ability in comparison to the other 2 species (Saint Pierre et al. 2002). Determination of the relative contribution of different mechanisms to plant competitive ability posses then a new interesting and difficult challenge for future research.

Similar or greater rates of ammonium uptake on defoliated than on undefoliated plants of all 3 species leads to rejection of the second hypothesis. Defoliation of some grass species has resulted in decreased nutrient uptake rates on nutrient-rich soils as a result of increased carbon allocation for shoot regrowth (Davidson and Milthorpe 1966, Ourry et al. 1989). Similar results were obtained in Agropyron desertorum (Fisch. ex Link) Schult. and A. spicatum Pursh. (Caldwell et al. 1987). Carbon can be the limiting factor when plants grow in nutrient-rich environments (Lambers et al. 1998). In nutrient-poor environments, however, regrowth can deplete nitrogen and phosphorus reserves more rapidly than those of carbohydrates (Chapin and Slack 1979). Because of this, plants could maintain or even increase nutrient uptake rates after defoliation at the expense of using fresh carbohydrates coming from aboveground, remnant tissues (Chapin and Slack 1979). For example, phosphate uptake was stimulated after a moderate defoliation in the grasses Eriophorum vaginatum L. and Carex aquatilis Wahlenb. when these species grew in a nutrient-limited environment (Chapin and Slack 1979). It is possible that defoliations of a greater frequency and/or intensity than those used in our study could lower ammonium uptake rates below values on undefoliated controls in $S$. clarazii, $S$. tenuis and $S$. ambigua. This would allow determination of the point where multiple defoliations deplete reserve carbohydrates such that ammonium uptake can no longer be maintained at high rates (Chapin and Slack 1979).

Greater capacity to rapidly modify root growth (Crick and Grime 1987) and greater root invasion rates (Eissenstat and Caldwell 1989) have been reported in grasses of relatively greater competitive ability. Plants with large root systems or high root proliferation rates can occupy greater soil volumes and thus gather a greater share of soil resources (Caldwell et al. 1987). Derner and Briske (1999) view root physiological and morphological plasticities as complementary rather than alternative traits. We reported ammonium uptake rates as $\mathrm{N}$ micrograms taken-up per gram root dry weight per hour, without considering total root system extension when making comparisons on a per plant basis. However, a parallel study at the study site demonstrated a greater root proliferation on defoliated and undefoliated plants of $S$. clarazii than on those of $S$. tenuis and $S$. ambigua (Saint Pierre et al. 2002). Thus, and in agreement with results of Derner and Briske (1999), ammonium uptake rates and root proliferation capacity appear as complementary mechanisms contributing to the greater competitive ability in $S$. clarazii than in the other species. However, Busso et al. (2001) found divergences between ammonium uptake capacity and response to defoliation in 2 perennial, late-successional, $\mathrm{C}_{4}$ grass species. They suggested that tradeoffs may exist between mechanisms associated with ammonium acquisition and herbivory resistance. These trade-offs did not appear to occur in our study, where the highly competitive $S$. clarazii (Saint Pierre 
2002), with greater ammonium uptake rates most of the time, was also the most grazing tolerant (Saint Pierre 2002, Saint Pierre et al. 2000 a, 2000b)

Greater competitive ability and defoliation tolerance in the late-seral $S$. clarazii than in the earlier-seral $S$. tenuis and $S$. ambigua would place $S$. clarazii as a dominant species in well managed grasslands. Our results are consistent with the hypothesis that late-seral species have a greater competitive ability than earlier-seral species (Wilson and Keddy 1986, Hendon and Briske 2002). At the study site, percentage contribution to total perennial grass biomass increased from 3.4 to $14.6 \%$ in $S$. clarazii and decreased from 27.5 to $13.1 \%$ in $S$. ambigua in areas which were excluded from domestic herbivory and had not been exposed to any disturbance during a 9-year period (Giorgetti et al. 1995). At the same time, frequency increased from $7.5 \pm 7.5$ to $15 \pm 8.7 \%$ (mean \pm 1 standard deviation) in S. clarazii and decreased from $65 \pm 13.2$ to $32.5 \pm 11.1 \%$ in S. ambigua (Giorgetti et al. 2000).

Stipa tenuis and S. ambigua showed a similar regrowth production after defoliation. Except on 4 December at $50 \mathrm{ppm}$, where undefoliated $S$. tenuis had significantly lower ammonium uptake rates than defoliated S. ambigua, or where defoliated $S$. tenuis showed significantly greater ammonium uptake rates than undefoliated $S$. ambigua, these 2 species also had similar $(\mathrm{P}>0.05)$ rates of ammonium uptake during the study period. These results indicate that herbivory tolerance and competitive ability would be similar in $S$. tenuis and $S$. ambigua. Our data suggest a competitive hierarchy of the form $S$. clarazii $>$ $S$. tenuis $=S$. ambigua. A parallel study at the same research site confirmed this competitive hierarchy. When labelled $\left({ }^{15} \mathrm{NH}_{4}\right)_{2}$ $\mathrm{SO}_{4}$ was introduced into the soil between any 3 species pair of defoliated or undefoliated plants of the 3 species, mean total $\mathrm{N}$ acquisition per basal area basis was significantly greater in $S$. clarazii $(0.0393 \mathrm{mg}$ ${ }^{15} \mathrm{~N}$ atom excess $\mathrm{cm}^{-2}$ ) than in $S$. tenuis and S. ambigua (Saint Pierre 2002). At the same time, S. tenuis and S. ambigua did not show significant differences in total $\mathrm{N}$ acquisition from the soil (mean $=0.011$ $\mathrm{mg}{ }^{15} \mathrm{~N}$ atom excess $\mathrm{cm}^{-2}$ in $S$. tenuis and $0.007 \mathrm{mg}^{15} \mathrm{~N}$ atom excess $\mathrm{cm}^{-2}$ in $S$. ambigua) (Saint Pierre 2002).

Nitrogen uptake rates increased with increasing $\mathrm{NH}_{4}^{+}$solution concentrations in all 3 species. This demonstrates the ability of the root system for increasing ammonium acquisition during favourable periods of resource availability. Results obtained when comparing defoliated ver- sus undefoliated plants suggest that photosynthetic canopy may be reestablished without sacrificing root function in these perennial grasses, at least when carbon reserves are not limiting. This study supported the greater defoliation tolerance in $S$. clarazii than in the other 2 species. Since $S$. clarazii was a superior competitor, it agrees with the report by Keddy (1990) that production of above-ground biomass is a good predictor of competitive ability. We also found a positive correlation between competitive ability and ammonium uptake rate. The superior competitor $S$. clarazii had greater ammonium uptake rates than $S$. tenuis and $S$. ambigua most of the time. Nutrient uptake rate in perennial grasses responds linearly with temperature (Chapin and Bloom 1976). In this manner, differences in ammonium uptake rates observed among treatments at $20^{\circ} \mathrm{C}$ in this study are most likely representative of those expected at other different temperatures (Chapin and Slack 1979). Further research on ammonium uptake rates of these species when growing with either defoliated or undefoliated nearby neighbors will increase our understanding of the importance of this process to plant function.

\section{Literature Cited}

Anderson, V.J. and D.D. Briske. 1995. Herbivore-induced species replacement in grasslands: is it driven by herbivory tolerance or avoidance? Ecol. Appl. 5:1014-1024.

Becker, G.F., C.A. Busso, T. Montani, M.A. Burgos, A.C. Flemmer, and M.B. Toribio, M. 1997. Effects of defoliating Stipa tenuis and Piptochaetium napostaense at different phenological stages. III. Root growth. J. Arid Environ. 35:269-283.

Bloom, A.J. and M.M. Caldwell. 1988. Root excision decreases nutrient absorption and gas fluxes. Plant Physiol. 87:794-796.

Briske, D.D. 1991. Developmental morphology and physiology of grasses, p. 85-108. In: R.K. Heitschmidt and J.W. Stuth (eds.) Grazing management. An ecological perspective: Timber Press, Inc, Portland, Ore.

Briske, D.D. and J.R. Hendrickson. 1998. Does selective defoliation mediate competitive interactions in a semiarid savanna? A demographic evaluation. J. Veg. Sci. 9:611-622.

Briske, D.D. and J.H. Richards. 1995. Plant responses to defoliation: A physiological, morphological and demographic evaluation, p. 635-710. In: D.J. Bedunah and R.E. Sosebee (eds.) Wildland plants: Physiological ecology and developmental morphology, Soc. for Range Manage., Denver, Colo.

Busso, C.A. 1997. Towards an increased and sustainable production in semiarid rangelands of Central Argentina: Two decades of research. J. Arid Environ. 36:197-210
Busso, C.A, D.D. Briske, and V. Olalde Portugal. 2001. Root traits associated with nutrient exploitation following defoliation in three coexisting perennial grasses in a semiarid savanna. Oikos 93:332-342.

Cabrera, A.L. 1976. Regiones fitogeográficas Argentinas, p. 1-85. In: E.F. Ferreira Sobral (ed.) Enciclopedia Argentina de Agricultura y Jardineria, Buenos Aires: ACME.

Caldwell, M.M. 1994. Exploiting nutrients in fertile soil microsites, p. 325-347. In: M.M. Caldwell and R.W. Pearcy (eds.) Exploitation of environmental heterogeneity by plants, Academic Press, Inc, San Diego, Calif.

Caldwell, M.M., J.H. Richards, J.H. Manwaring, and D.M. Eissenstat. 1987. Rapid shifts in phosphate acquisition show direct competition between neighbouring plants. Nature 327:615-616.

Caldwell, M.M., J.H. Richards, D.A. Johnson, R.S. Nowak, and R.S. Dzurec. 1981. Coping with herbivory: photosynthetic capacity and resource allocation in two semiarid Agropyron bunchgrasses. Oecologia 50: 178-184.

Cano, E. 1988. Pastizales naturales de La Pampa. Descripci6n de las especies mas importantes. Tomo 1. Convenio AACREAProvincia de La Pampa, La Pampa.

Casper, B.B. and R.B. Jackson. 1997. Plant competition underground. Annu. Rev. Ecol. Syst. 28: 545-570.

Chapin, F.S. III. and A. Bloom. 1976. Phosphate absorption: adaptations of tundra graminoids to a low temperature, low phosphorus environments. Oikos 26:111-121.

Chapin, F.S. III. and M. Slack. 1979. Effect of defoliation upon root growth, phosphate absorption and respiration in nutrient-limited tundra graminoids. Oecologia (Berl) 42:67-79.

Crick, J.C. and J.P. Grime. 1987. Morphological plasticity and mineral nutrient capture in two herbaceous species of contrasted ecology. New Phytol. 107:403-414.

Davidson, J.L. and F.L. Milthorpe. 1966. The effect of defoliation on the carbon balance in Dactylis glomerata. Ann. Bot. 30:185-198.

Derner, J.D. and D.D. Briske. 1999. Does a tradeoff exist between morphological root plasticity? A comparison of grass growth forms. Acta Oecol. 20 (5):519-526.

Di Tommaso, A. and L.W. Aarssen. 1991. Effect of nutrient level on competition intensity in the field for three coexisting grass species. J. Veg. Sci. 2:513-522.

Eissenstat, D.M. and M.M. Caldwell. 1989. Invasive root growth into disturbed soil of two tussock grasses that differ in competitive effectiveness. Funct. Ecol. 3:345-353.

Fiedler, R. and G. Proksch. 1975. The determination of Nitrogen- 15 by emission and mass spectrometry in biochemical analysis: a review. Anal Chim. Acta 78:1-62.

Giorgetti, H.D., O.A. Montenegro, G.D. Rodriguez, and C.A. Busso. 2000. Frecuencia de especies herbaceas y leñosas en pastizales naturales del centro de Argentina recobrandose de disturbios. XXIII 
Congreso Argentino de Produccion Animal, Corrientes, Argentina. p. 138-139.

Giorgetti, H.D., O.A. Montenegro, G.D. Rodriguez, C.A. Busso, T. Montani, M.A. Burgos, A.C. Flemmer, B. Toribio, and S.S. Horvitz. 1995. Biomasa de especies herbáceas y su correlaci6n con la precipitaci6n en la Provincia Fitogeográfica del Monte, XVII Reuni6n Argentina de Ecologia, Mar del Plata, Argentina. p. 166.

Giorgetti, H.D., O.A. Montenegro, G.D. Rodriguez, C.A. Busso, T. Montani, M.A. Burgos, A.C. Flemmer, B. Toribio, and S.S. Horvitz. 1997. The comparative influence of past management and rainfall on range herbaceous standing crop in east central Argentina: 14 years of observations. J. Arid Environ. 36:623-637

Grime, J.P. 1994. The role of plasticity in exploiting environmental heterogeneity, $p$. 1-9. In: M.M. Caldwell and R.W. Pearcy (eds.) Exploitation of environmental heterogeneity by plants-ecophysiological processes above and belowground Academic Press, San Diego, Calif.

Hendon, B.C. and D.D. Briske. 2002. Relative herbivory tolerance and competitive ability in two dominant subordinate pairs of perennial grasses in a native grassland. Plant Ecol. 160: 43-51.

Jackson, R.B. and M.M. Caldwell. 1989. The timing and degree of root proliferation in fertile-soil microsites for three cold-desert perennials. Oecologia 81:149-153.

Jackson, R.B. and M.M. Caldwell. 1991. Kinetic responses of Pseudoroegneria roots to localized soil enrichment. Plant Soil 138:231-238.

Jackson, R.B., J.H. Manwaring, and M.M. Caldwell. 1990. Rapid physiological adjustment of roots to localized soil enrichment. Nature 344:58-60.

Jackson, R.B., W.T. Pockman, and W.A. Hoffmann. 1999. The structure and function of root systems, p. 195-220. In: F.I. Pugnaire and F. Valladares (eds.) Handb. of Functional Plant Ecol., N. Y.

Keddy, P.A. 1990. Competitive hierarchies and centrifugal organization in plant communities, p. 266-290. In: J.B. Grace and D. Tilman (eds.) Perspective on plant competition: Academic Press, San Diego, Calif.

Lambers, H., F. Stuart Chapin III, and T.L. Pons. 1998. Plant Phys. Ecol.. SpringerVerlag, New York, N. Y.

Larigauderie, A. and J.H. Richards. 1994. Root proliferation characteristics of seven perennial arid-land grasses in nutrientenriched microsites. Oecologia 99:102-111.

Lazzari, M.A., G.C. Lurent, and R.L. Victoria. 1991. Destino del ${ }^{15} \mathrm{~N}$ del fertilizante aplicado al trigo durante dos años consecutivos en condiciones semiaridas. Suelo y Planta 1:179-188.

Moretto, A. and R.A. Distel. 1997. Competitive interactions between palatable and unpalatable grasses native to a temperate semi-arid grassland of Argentina. Plant Ecol. 130:155-161.
Nye, P.H. and P.B. Tinker. 1977. Solute movement in the soil-root system. Blackwell Scientific, London, United Kingdom.

Ourry, A., B. Gonzalez, J. Bigot, J Boucaud, and J. Salette. 1989. Nitrogen and carbohydrate mobilizations during regrowth of defoliated Lolium perenne L. p. 513-514. Proc. of the XVI International Grassland Congress, Nice, France.

Polley, H.W. and J.K. Detling. 1989. Defoliation, nitrogen and competition effects on plant growth and nitrogen nutrition. Ecol. 70: 721-727.

Rideout, J.W. and C.D. Jr. Raper. 1994. Diurnal changes in net uptake rate of nitrate are associated with changes in estimated export of carbohydrates to roots. Int. J. Plant Sci. 155:173-179.

Rittemberg, D. 1948. Preparation and measurement of isotopic tracers, p. 31-42. In: D.W. Wilson, A.O.C. Nier and S.P. Riechman (eds.) Edwards, Ann Arbor, Mich.

Sanderson, M.A., D.W. Stair, and M.A. Hussey. 1997. Physiological and morphological responses of perennial forages to stress. Advan. Agron. 59:171-224.

Saint Pierre, C. 2002. Capacidad competitiva y tolerancia a la defoliacion en Stipa clarazii, Stipa tenuis y Stipa ambigua. M.Sc. Thesis. Universidad Nacional del Sur. Bahia Blanca, Buenos Aires, 81 pp.

Saint Pierre C., C.A. Busso, O.A. Montenegro, G.D. Rodríguez, H.D. Giorgetti, and T. Montani. 2000a. Demografia y crecimiento en especies de gramineas nativas del Sur de la Provincia Fitogeográfica del Monte. XVI Reunion Latinoamericana de Produccion Animal y III Congreso Uruguayo de Produccion Animal. Montevideo, Uruguay. Available in CDROM.

Saint Pierre C., C.A. Busso, O.A. Montenegro, G.D. Rodriguez, H.D. Giorgetti, and T. Montani. 2000b. Produccion de materia seca en especies de gramineas perennes nativas del Centro de Argentina. XVI Reunion Latinoamericana de Produccion Animal y III Congreso Uruguayo de Produccion Animal. Montevideo, Uruguay. Available in CD-ROM

Saint Pierre, C., C.A. Busso, O.A. Montenegro, G.D. Rodriguez, H.D. Giorgetti, T. Montani, and O.A. Bravo. 2002. Root proliferation in perennial grasses of low and high palatability. Plant Ecology 165: 161-169.

Sanchez, J.P. and M.A. Lazzari. 1999. Impact of fire on soil nitrogen forms in central semiarid Argentina. Arid Soil Res. Rehab. 13:81-90.

Stark, J.M. 1994. Causes of soil nutrient heterogeneity at different scales, p. 255-284. In: M.M. Caldwell and R.W. Pearcy (eds.) Exploitation of environmental heterogeneity by plants: Ecological Processes Above- and Belowground: Academic Press, New York, N.Y.

Steel, R.G. and J.H. Torrie. 1981. Principles and procedures of statistics. McGraw-Hill Company, New York, N.Y.
Torrea M.B., H.M. Arelovich, M.I. Amela, D.A. Pevsner, and C.A. Busso. 2000. Caracteristicas nutritivas de Stipa tenuis y Piptochaetium napostaense, dos gramineas nativas del Caldenal. XVI Reunion Latinoamericana de Produccion Animal y III Congreso Uruguayo de Produccion Animal. Montevideo, Uruguay. Available in CDROM.

Van Auken, O.W. and J.K. Bush. 1997. The importance of neighbors, soil $\mathrm{pH}$, phosphorus, and nitrogen for the growth of two $\mathrm{C}_{4}$ grasses. Int. J. Plant Sci. 158:325-331.

Vucinic, Z. and M. Vuletic. 1995. The effect of addition of sucrose on the energy status and the trans-root electric potential difference of excised maize roots. Plant Cell. Physiol. 36:45-52.

Wallace, L.L. 1981. Growth, morphology and gas exchange of mycorrhizal and nonmycorrhizal Panicum coloratum $\mathrm{L}$., a $\mathrm{C}_{4}$ grass species, under different clipping and fertilization regimes. Oecologia 49: 272-278.

Wallace, L.L. and S.A. Macko. 1993. Nutrient acquisition by clipped plants as a measure of competitive success: the effects of compensation. Funct. Ecol: 326-331.

Wilson, S.D. and P.A. Keddy. 1986. Species competitive ability and position along a natural stress/disturbance gradient. Ecol. 67: 1236-1242. 